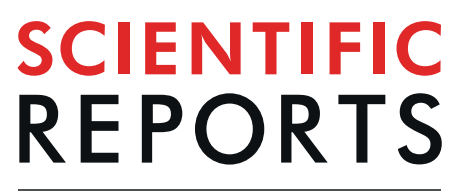

natureresearch

\title{
Nitrogen supply modulates nitrogen remobilization and nitrogen use of wheat under supplemental irrigation in the North China Plain
}

\begin{abstract}
Xuejiao Zheng, Zhenwen Yu, Yongli Zhang* \& Yu Shi
Excessive nitrogen $(\mathrm{N})$ input and irrigation exacerbate $\mathrm{N}$ leaching in winter wheat production in the North China Plain (NCP). To explore the optimal $\mathbf{N}$ for better $\mathrm{N}$ remobilization and higher $\mathrm{N}$ utilization of wheat under water-saving irrigation will be conductive to less environmental contamination. A field experiment was conducted at $300\left(\mathrm{~N}_{300}\right), 240\left(\mathrm{~N}_{240}\right), 180\left(\mathrm{~N}_{180}\right)$, and $0\left(\mathrm{~N}_{0}\right) \mathrm{kg} \mathrm{N} \mathrm{ha}^{-1}$ of $\mathrm{N}$ application under supplemental irrigation (SI) that brought the relative soil water content (RSWC) to $70 \%$ at jointing and $65 \%$ at anthesis. Compared with $\mathrm{N}_{0}, \mathrm{~N}_{180}$ improved the free amino acid content in the flag leaf and grain after anthesis, dry matter and plant $\mathrm{N}$ accumulation at maturity, $\mathrm{N}$ translocation amount of vegetable organs and its contribution to grain from anthesis to maturity. Compared to $\mathrm{N}_{240}$ and $\mathrm{N}_{300}$, $\mathrm{N}_{180}$ increased the $\mathrm{N}$ translocation efficiency of vegetable organs, and reduced the soil $\mathrm{NO}_{3}-\mathrm{N}$ residue in the $60-180 \mathrm{~cm}$ soil layer, which contributing to no significant reduction in grain yield and grain protein yield, but higher grain $\mathrm{N}$ recovery efficiency $\left({ }^{(} R E_{N}\right), N$ recovery efficiency $\left(R E_{N}\right)$, and $N$ partial factor productivity $\left(\mathrm{PFP}_{\mathrm{N}}\right)$. Positive relationships were found between leaf $\mathrm{N}$ translocation efficiency and grain yield, grain protein yield, $\mathrm{PFP}_{\mathrm{N}},{ }^{G} \mathrm{RE}_{\mathrm{N}}$, and $\mathrm{RE} \mathrm{N}_{\mathrm{N}}$. Therefore, $\mathrm{N}_{180}$ is appropriate to obtain a steady grain yield over $7.5 \mathrm{t} \mathrm{ha}^{-1}$ for at least 2 years under SI based on RSWC in the NCP.
\end{abstract}

As a main grain-producing area, the output of the North China Plain (NCP) accounts for approximately $61 \%$ of China's total wheat production ${ }^{1}$. However, to continuously maximize crop yield, the traditional nitrogen $(\mathrm{N})$ cultivation practices of farmers are high, at up to $\geq 300 \mathrm{~kg} \mathrm{~N} \mathrm{ha}^{-1}$, which threatens the ecological safety of the area ${ }^{2-4}$. A constant increase in $\mathrm{N}$ input decreases the $\mathrm{N}$ use efficiency, leading to large amounts of nitrate $\mathrm{N}$ leaching in soil, gaseous $\mathrm{N}$ losse and environmental $\mathrm{N}$ pollution ${ }^{5-7}$.

$\mathrm{N}$ plays an essential role in plant growth and, therefore, to agricultural production ${ }^{8}$. $\mathrm{N}$ yield is derived from two sources: (1) stored $\mathrm{N}$ in vegetative parts before anthesis, and (2) $\mathrm{N}$ uptake during grain filling ${ }^{9,10}$. The amount of $\mathrm{N}$ remobilized to the grain largely depends on $\mathrm{N}$ stored at anthesis, and post-anthesis $\mathrm{N}$ remobilization efficiency of wheat increased from 67 to $71 \%$ when $\mathrm{N}$ input increased from 109 to $227 \mathrm{~kg} \mathrm{~N} \mathrm{ha}^{-111,12}$. N distribution in wheat tissues is closely related to the productivity of its canopy, and high yield or high-quality grain in wheat requires the application and uptake of high levels of $\mathrm{N}$ fertilizer ${ }^{13,14}$. However, increasing $\mathrm{N}$ application does not always lead to a commensurate increase in grain yield ${ }^{15}$. Additionally, water availability affects the chemical form of $\mathrm{N}$ in all phases of the $\mathrm{N}$ cycle ${ }^{16}$. Previous studies have shown that conditions of moderate soil moisture are beneficial for $\mathrm{N}$ availability and uptake, and hence plant growth and yield ${ }^{17-19} .100 \%$ full irrigation increased $\mathrm{N}$ accumulation in grain at maturity by $15.9 \%$ and grain yield by $17.1 \%$, respectively, compared with $50 \%$ full irrigation $^{20}$. The use of an appropriate irrigation regime can enhance $\mathrm{N}$ uptake and reduce $\mathrm{N}$ loss ${ }^{21}$. Thus, $\mathrm{N}$ supply combined with optimization of supplemental irrigation (SI) is necessary to increase $\mathrm{N}$ uptake and reduce soil $\mathrm{NO}_{3}$-N leaching.

Previous studies have applied water-saving technology to determine the amount of SI based on the relative soil water content (RSWC), considering changes in precipitation and soil water availability, which is an important way 


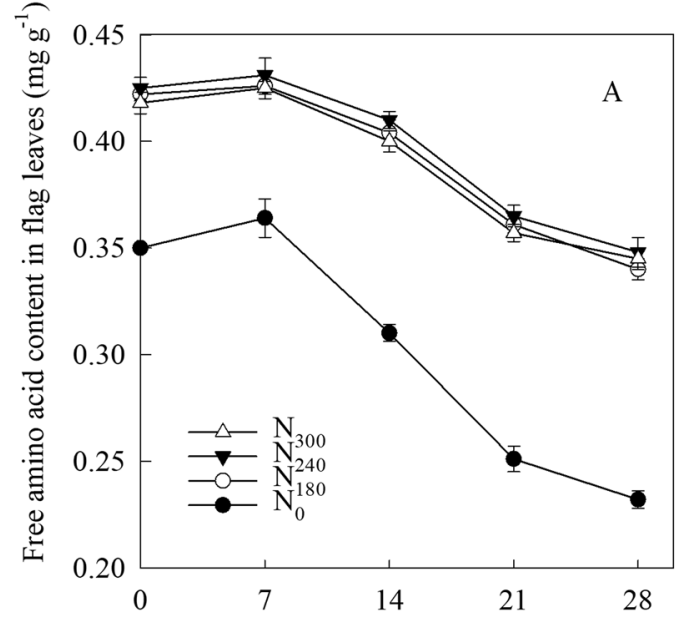

Day after anthesis $(d)$

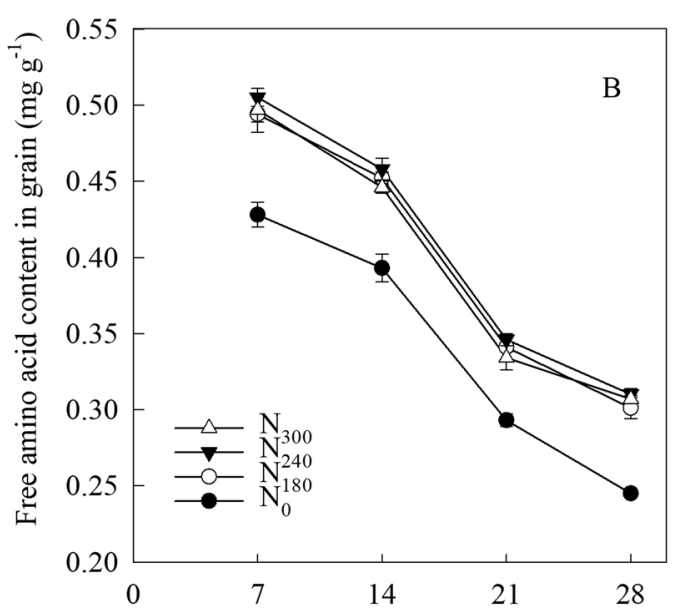

Day after anthesis (d)

Figure 1. Changes of free amino acid content in wheat flag leaf $(\mathbf{A})$ and grain $(\mathbf{B})$ under different $\mathrm{N}$ treatments in 2016/2017. $\mathrm{N}_{300}, \mathrm{~N}_{240}, \mathrm{~N}_{180}$ and $\mathrm{N}_{0}$ represent $\mathrm{N}$ application rate at $300,240,180$ and $0 \mathrm{~kg} \mathrm{~N} \mathrm{ha}{ }^{-1}$, respectively. Vertical bars represent standard deviation of the means.

\begin{tabular}{|c|c|c|c|c|c|c|c|c|c|c|c|}
\hline \multirow[b]{2}{*}{ Year } & \multirow{2}{*}{ Treatment } & \multicolumn{5}{|c|}{ Dry matter accumulation $\left(\mathrm{t} \mathrm{ha}^{-1}\right)$} & \multicolumn{5}{|c|}{ Plant $\mathrm{N}$ accumulation $\left(\mathrm{kg} \mathrm{ha}^{-1}\right)$} \\
\hline & & Pre-winter & Revival & Jointing & Anthesis & Maturity & Pre-winter & Revival & Jointing & Anthesis & Maturity \\
\hline \multirow[t]{4}{*}{$2015 / 2016$} & $\mathrm{~N}_{300}$ & $0.870 \mathrm{a}$ & $1.99 \mathrm{a}$ & $4.93 \mathrm{a}$ & $11.5 \mathrm{a}$ & $17.1 \mathrm{a}$ & $30.7 \mathrm{a}$ & 78.9a & $156 \mathrm{a}$ & $215 \mathrm{a}$ & $262 \mathrm{ab}$ \\
\hline & $\mathrm{N}_{240}$ & $0.862 \mathrm{a}$ & $1.98 \mathrm{a}$ & $5.00 \mathrm{a}$ & $11.6 \mathrm{a}$ & $17.3 \mathrm{a}$ & $30.3 \mathrm{ab}$ & $79.4 \mathrm{a}$ & $158 \mathrm{a}$ & $219 \mathrm{a}$ & $272 \mathrm{a}$ \\
\hline & $\mathrm{N}_{180}$ & $0.834 \mathrm{a}$ & $1.95 \mathrm{a}$ & $4.86 \mathrm{a}$ & $11.1 \mathrm{a}$ & $16.8 \mathrm{a}$ & $29.0 \mathrm{~b}$ & $75.4 \mathrm{a}$ & $154 \mathrm{a}$ & $208 \mathrm{a}$ & $256 \mathrm{~b}$ \\
\hline & $\mathrm{N}_{0}$ & $0.666 \mathrm{~b}$ & $1.60 \mathrm{~b}$ & $3.89 \mathrm{~b}$ & $9.88 \mathrm{~b}$ & $13.8 \mathrm{~b}$ & $21.2 \mathrm{c}$ & $56.5 \mathrm{~b}$ & $125 \mathrm{~b}$ & $135 \mathrm{~b}$ & $194 \mathrm{c}$ \\
\hline \multirow[t]{4}{*}{$2016 / 2017$} & $\mathrm{~N}_{300}$ & $0.729 a$ & $2.52 \mathrm{a}$ & $5.65 a$ & $12.2 \mathrm{~b}$ & $17.3 \mathrm{~b}$ & $30.7 \mathrm{a}$ & $94.9 \mathrm{a}$ & $177 \mathrm{a}$ & $214 \mathrm{~b}$ & $279 b$ \\
\hline & $\mathrm{N}_{240}$ & $0.719 \mathrm{a}$ & $2.52 \mathrm{a}$ & $5.77 \mathrm{a}$ & $12.8 \mathrm{a}$ & $18.2 \mathrm{a}$ & $30.2 \mathrm{a}$ & $94.2 \mathrm{a}$ & $183 \mathrm{a}$ & $224 \mathrm{a}$ & $297 \mathrm{a}$ \\
\hline & $\mathrm{N}_{180}$ & $0.689 \mathrm{a}$ & $2.47 \mathrm{a}$ & $5.67 \mathrm{a}$ & $12.3 \mathrm{ab}$ & $17.7 \mathrm{ab}$ & $28.4 \mathrm{a}$ & $90.7 \mathrm{a}$ & $181 \mathrm{a}$ & $213 b$ & $285 \mathrm{ab}$ \\
\hline & $\mathrm{N}_{0}$ & $0.603 \mathrm{~b}$ & $1.82 \mathrm{~b}$ & $4.24 \mathrm{~b}$ & $10.8 \mathrm{c}$ & $14.9 \mathrm{c}$ & $24.6 \mathrm{~b}$ & $64.5 \mathrm{~b}$ & $136 \mathrm{~b}$ & $146 \mathrm{c}$ & $206 c$ \\
\hline \multicolumn{12}{|l|}{ ANOVA } \\
\hline Nitrogen $(\mathrm{N})$ & & $* * *$ & $* * *$ & $* * *$ & $* * *$ & $* * *$ & $* * *$ & $* * *$ & $* * *$ & $* * *$ & $* * *$ \\
\hline Year $(\mathrm{Y})$ & & $* * *$ & $* * *$ & $* * *$ & $* * *$ & $* * *$ & ns & $* * *$ & $* * *$ & $*$ & $* * *$ \\
\hline $\mathrm{N} \times \mathrm{Y}$ & & $*$ & $* * *$ & $* *$ & ns & ns & $*$ & $\mathrm{~ns}$ & ns & ns & ns \\
\hline
\end{tabular}

Table 1. Dry matter accumulation and plant $\mathrm{N}$ accumulation of wheat at different growth stages under different $\mathrm{N}$ treatments in 2015/2016 and 2016/2017 $\left(\mathrm{kg} \mathrm{ha}^{-1}\right) . \mathrm{N}_{300}, \mathrm{~N}_{240}, \mathrm{~N}_{180}$ and $\mathrm{N}_{0}$ represent $\mathrm{N}$ application rate at 300, 240, 180 and $0 \mathrm{~kg} \mathrm{~N} \mathrm{ha}^{-1}$, respectively. Different letters indicate statistical significance at $\mathrm{P}<0.05$ among treatments. *Significant at $\mathrm{P}<0.05$. **Significant at $\mathrm{P}<0.01$. ***Significant at $\mathrm{P}<0.001$. ns, not significant, $\mathrm{P} \geq 0.05$.

to achieve high yield and water use efficiency in winter wheat production ${ }^{22,23}$. However, few studies have focused on the response of $\mathrm{N}$ uptake, translocation, and $\mathrm{N}$ use following $\mathrm{N}$ fertilizer application under conditions of SI based on the RSWC. Therefore, in this study, we applied $\mathrm{N}$ at four rates with a target RSWC at jointing and at anthesis. The objectives of the present study were: (1) to clarify the changes in $\mathrm{N}$ accumulation and translocation in individual organs of wheat in response to $\mathrm{N}$ input; (2) to quantify the dynamics of soil $\mathrm{NO}_{3}-\mathrm{N}_{\text {content in the }}$ $0-200 \mathrm{~cm}$ soil layer, and (3) to determine the optimal rate of N application under SI based on RSWC to maintain higher grain yield and higher N utilization in the NCP.

\section{Results}

Free amino acid content in flag leaves. $\mathrm{N}$ input significantly influenced the free amino acid content in flag leaves after anthesis (Fig. 1A) in 2016/2017. Compared with $\mathrm{N}_{0}, \mathrm{~N}_{180}$ resulted in a higher content of free amino acids in flag leaves at $0,7,14,21$, and 28 days after anthesis, and there was no significant differences in those between $\mathrm{N}_{180}, \mathrm{~N}_{240}$, and $\mathrm{N}_{300}$. $\mathrm{N}_{0}$ significantly decreased the free amino acid content in grain at $7,14,21$, and 28 days after anthesis compared with other $\mathrm{N}$ inputs (Fig. 1B). No significant differences in free amino acid content were observed in grain after anthesis between the $\mathrm{N}_{180}, \mathrm{~N}_{240}$, and $\mathrm{N}_{300}$ treatments.

Dry matter and plant $\mathbf{N}$ accumulation. Dry matter accumulation (DMA) of wheat at different stages was significantly affected by $\mathrm{N}$ and year during the wheat growing seasons studied; however, $\mathrm{N} \times$ year interaction had no significant effects on DMA at anthesis and maturity (Table 1). The DMA in $\mathrm{N}_{180}$ significantly 


\begin{tabular}{|c|c|c|c|c|c|c|c|}
\hline \multirow[b]{2}{*}{ Year } & \multirow[b]{2}{*}{ Treatment } & \multicolumn{2}{|c|}{$\begin{array}{l}\mathrm{N} \text { translocation } \\
\text { amount }\left(\mathrm{kg} \mathrm{ha}^{-1}\right)\end{array}$} & \multicolumn{2}{|c|}{$\begin{array}{l}\mathrm{N} \text { translocation } \\
\text { efficiency (\%) }\end{array}$} & \multicolumn{2}{|c|}{$\begin{array}{l}\mathrm{N} \text { contribution to } \\
\text { grain }(\%)\end{array}$} \\
\hline & & STS & Leaf & STS & Leaf & STS & Leaf \\
\hline \multirow[t]{4}{*}{$2015 / 2016$} & $\mathrm{~N}_{300}$ & $79.6 \mathrm{a}$ & $57.3 \mathrm{a}$ & $78.8 \mathrm{~b}$ & $80.4 \mathrm{~b}$ & $41.0 \mathrm{a}$ & $29.5 a$ \\
\hline & $\mathrm{N}_{240}$ & $82.9 \mathrm{a}$ & $58.5 \mathrm{a}$ & $79.0 \mathrm{~b}$ & $79.8 \mathrm{~b}$ & $41.0 \mathrm{a}$ & $28.9 \mathrm{a}$ \\
\hline & $\mathrm{N}_{180}$ & $79.6 \mathrm{a}$ & $58.4 \mathrm{a}$ & $80.4 \mathrm{a}$ & $82.3 \mathrm{a}$ & $40.8 \mathrm{a}$ & $29.9 a$ \\
\hline & $\mathrm{N}_{0}$ & $49.4 \mathrm{~b}$ & $31.4 \mathrm{~b}$ & $75.6 \mathrm{c}$ & $76.4 \mathrm{c}$ & $33.5 \mathrm{~b}$ & $21.2 \mathrm{~b}$ \\
\hline \multirow[t]{4}{*}{$2016 / 2017$} & $\mathrm{~N}_{300}$ & $77.7 \mathrm{~b}$ & $50.4 \mathrm{a}$ & $72.2 \mathrm{~b}$ & $81.5 \mathrm{~b}$ & $35.6 \mathrm{a}$ & $23.1 \mathrm{a}$ \\
\hline & $\mathrm{N}_{240}$ & $84.8 \mathrm{a}$ & $52.0 \mathrm{a}$ & $73.0 \mathrm{~b}$ & $81.6 \mathrm{~b}$ & $36.3 a$ & $22.2 \mathrm{a}$ \\
\hline & $\mathrm{N}_{180}$ & $82.7 \mathrm{a}$ & $49.8 \mathrm{a}$ & $74.7 \mathrm{a}$ & $83.4 \mathrm{a}$ & $36.4 \mathrm{a}$ & $21.9 \mathrm{a}$ \\
\hline & $\mathrm{N}_{0}$ & $51.3 \mathrm{c}$ & $30.6 \mathrm{~b}$ & $70.3 \mathrm{c}$ & $79.6 \mathrm{c}$ & $31.5 \mathrm{~b}$ & $18.8 \mathrm{~b}$ \\
\hline \multicolumn{8}{|l|}{ ANOVA } \\
\hline Nitrogen $(\mathrm{N})$ & & *** & *** & $* * *$ & *** & *** & *** \\
\hline Year (Y) & & ns & $* * *$ & $* * *$ & $* * *$ & *** & $* * *$ \\
\hline $\mathrm{N} \times \mathrm{Y}$ & & ns & $*$ & ns & ns & ns & $* *$ \\
\hline
\end{tabular}

Table 2. $\mathrm{N}$ translocation of vegetable organs in wheat and its contribution to grain from anthesis to maturity under different $\mathrm{N}$ treatments in 2015/2016 and 2016/2017. $\mathrm{N}_{300}, \mathrm{~N}_{240}, \mathrm{~N}_{180}$ and $\mathrm{N}_{0}$ represent $\mathrm{N}$ application rate at 300, 240, 180 and $0 \mathrm{~kg} \mathrm{~N} \mathrm{ha}^{-1}$, respectively. STS, Stem and sheath. Different letters indicate statistical significance at $\mathrm{P}<0.05$ among treatments. *Significant at $\mathrm{P}<0.05$. **Significant at $\mathrm{P}<0.01$. ***Significant at $\mathrm{P}<0.001$. ns, not significant, $\mathrm{P} \geq 0.05$.

increased by $25.23,21.88,24.94,12.35$, and $21.74 \%$, respectively, compared with $\mathrm{N}_{0}$ in the pre-winter, revival and jointing, anthesis, and maturity stages in 2015/2016. When $\mathrm{N}$ input increased to $\mathrm{N}_{240}$ and $\mathrm{N}_{300}$, there were no significant increases in DMA. Higher DMA in the pre-winter, revival and jointing, anthesis, and maturity stages in $2016 / 2017$ was obtained with $\mathrm{N}_{180}$ compared with $\mathrm{N}_{0}$; there were no significant differences in this variable between $\mathrm{N}_{180}, \mathrm{~N}_{240}$, and $\mathrm{N}_{300}$.

$\mathrm{N}$ significantly affected $\mathrm{N}$ accumulation in plants at different stages, and there were no interactions between year and $\mathrm{N}$ treatment (except for $\mathrm{N}$ accumulation in plants at pre-winter) (Table 1). In 2015/2016, $\mathrm{N}_{180}$ significantly increased plant $\mathrm{N}$ accumulation in the pre-winter, revival and jointing, anthesis, and maturity stages compared with $\mathrm{N}_{0}$, and no differences were observed between $\mathrm{N}_{180}, \mathrm{~N}_{240}$, and $\mathrm{N}_{300}$. In $2016 / 2017$, although $\mathrm{N}_{240}$ treatment resulted in the highest plant $\mathrm{N}$ accumulation at anthesis, the plant $\mathrm{N}$ accumulation in the pre-winter, revival and jointing, and maturity stages was significantly increased up to $\mathrm{N}_{180}$ compared with $\mathrm{N}_{0}$, with no differences between $\mathrm{N}_{180}, \mathrm{~N}_{240}$, and $\mathrm{N}_{300}$ treatments.

$\mathrm{N}$ translocation from anthesis to maturity. The $\mathrm{N}$ translocation amount, $\mathrm{N}$ translocation efficiency, and $\mathrm{N}$ contribution to grain in stem and sheath (STS), and leaf from anthesis to maturity were significantly affected by $\mathrm{N}$ and year (except for $\mathrm{N}$ translocation amount in the STS) (Table 2). Compared with $\mathrm{N}_{0}, \mathrm{~N}$ translocation amount in the STS and leaf following application of $\mathrm{N}_{180}$ were increased by 61.13 and $85.99 \%$ in $2015 / 2016$, and 61.21 and $62.75 \%$ in 2016/2017, respectively, with no obvious differences between $\mathrm{N}_{180}, \mathrm{~N}_{240}$ and $\mathrm{N}_{300} . \mathrm{N}_{180}$ resulted in the highest $\mathrm{N}$ translocation efficiency in the STS and leaf among $\mathrm{N}$ treatments in both years. Compared with $\mathrm{N}_{0}, \mathrm{~N}_{180}$ significantly increased the STS and leaf N contribution to grain; there were no further increases with an increase in $\mathrm{N}$ application up to $\mathrm{N}_{240}$ and $\mathrm{N}_{300}$.

Distribution of $\mathbf{N}$ in different organs. As shown in Fig. 2, $\mathrm{N}$ distribution was highest in the grain at maturity, and lowest in the leaf in both years. $\mathrm{N}_{0}$ resulted in the lowest amount of $\mathrm{N}$ distributed in different organs. The highest amount of $\mathrm{N}$ was distributed in the stem and sheath following treatment with $\mathrm{N}_{240}$, followed by $\mathrm{N}_{300}$, and then $\mathrm{N}_{180}$ in both years. $\mathrm{N}_{180}$ decreased the amount of $\mathrm{N}$ distributed in the leaf, which decreased by 15.46 and $10.51 \%$ with $\mathrm{N}_{240}$ and $\mathrm{N}_{300}$, respectively, in $2015 / 2016$, and decreased by 15.13 and $12.82 \%$ in $2016 / 2017$. The amount of $\mathrm{N}$ distributed in the spike stalk and shell, and grain with $\mathrm{N}_{180}$ increased by 40.03 and $32.26 \%$ in $2015 / 2016$, respectively, and 36.97 and $39.94 \%$ in $2016 / 2017$ compared with $\mathrm{N}_{0}$, with no obvious differences observed between the $\mathrm{N}_{240}$ and $\mathrm{N}_{300}$ groups.

Soil $\mathrm{NO}_{3}-\mathrm{N}$ residue. $\mathrm{N}$ input significantly affected soil $\mathrm{NO}_{3}-\mathrm{N}$ residue in the $0-200 \mathrm{~cm}$ soil layer at maturity (Fig. 3). The lowest soil $\mathrm{NO}_{3}-\mathrm{N}$ residue in the 0-200 cm layer was obtained with $\mathrm{N}_{0}$ in both years. In 2015/2016, $\mathrm{N}_{300}$ resulted in the highest soil $\mathrm{NO}_{3}-\mathrm{N}$ residue in the $0-20 \mathrm{~cm}$ layer, followed by $\mathrm{N}_{240}$, and then $\mathrm{N}_{180}$. No obvi-

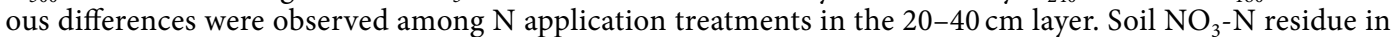
the 60-180 cm layer with $\mathrm{N}_{180}$ was lower than that with $\mathrm{N}_{240}$ and $\mathrm{N}_{300}$. In $2016 / 2017$, the soil $\mathrm{NO}_{3}-\mathrm{N}_{\text {residue in }}$ the 0-20 cm layer was similar to that observed in 2015/2016. $\mathrm{N}_{180}$ and $\mathrm{N}_{240}$ decreased the soil $\mathrm{NO}_{3}-\mathrm{N}$ residue in the 20-40 cm layer compared with $\mathrm{N}_{300} . \mathrm{N}_{180}$ significantly decreased the soil $\mathrm{NO}_{3}-\mathrm{N}$ residue in the $40-180 \mathrm{~cm}$ soil layer compared with $\mathrm{N}_{240}$ and $\mathrm{N}_{300}$, and no obvious differences were observed among $\mathrm{N}$ treatments in the $180-200 \mathrm{~cm}$ layer.

Grain yield, grain protein yield, and $\mathbf{N}$ utilization. The spike number, 1000-grain weight and grain yield were significantly affected by $\mathrm{N}$ rates and showed significant yearly variations, while there were no significant $\mathrm{N} \times$ year interactions on grain number per spike and grain yield (Table 3 ). Compared with $\mathrm{N}_{0}, \mathrm{~N}_{180}$ increased 


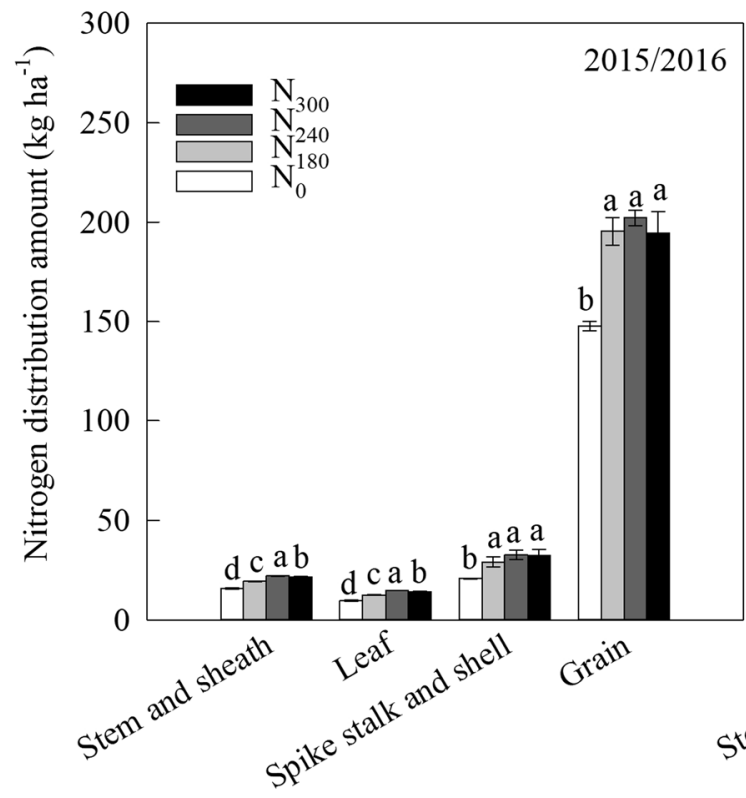

Plant organ

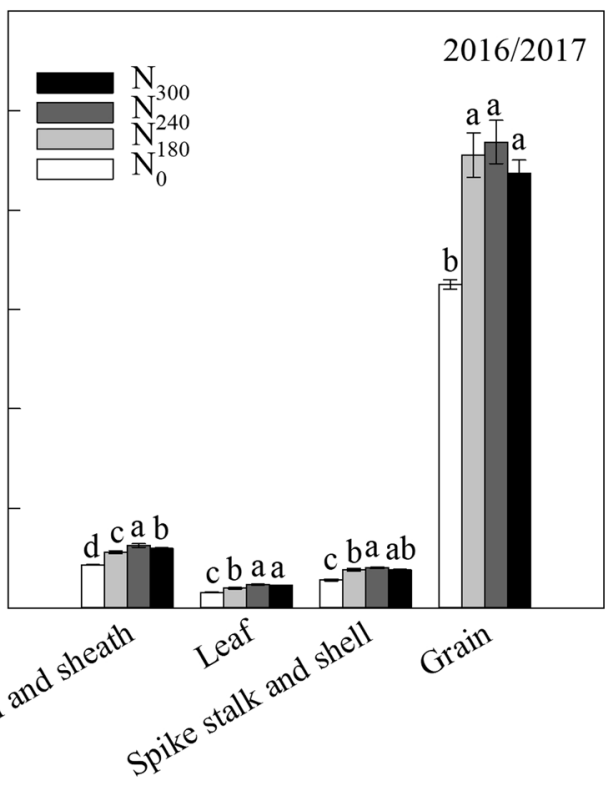

Plant organ

Figure 2. Amount of $\mathrm{N}$ distribution in wheat at maturity under different $\mathrm{N}$ treatments in $2015 / 2016$ and $2016 / 2017\left(\mathrm{~kg} \mathrm{ha}^{-1}\right) . \mathrm{N}_{300}, \mathrm{~N}_{240}, \mathrm{~N}_{180}$ and $\mathrm{N}_{0}$ represent $\mathrm{N}$ application rate at $300,240,180$ and $0 \mathrm{~kg} \mathrm{~N} \mathrm{ha}^{-1}$, respectively. Vertical bars represent standard deviation of the means. Different letters indicate statistical significance at $\mathrm{P}<0.05$ among treatments.

$$
\mathrm{NO}_{3}-\mathrm{N} \text { residue }\left(\mathrm{kg} \mathrm{ha}^{-1}\right)
$$

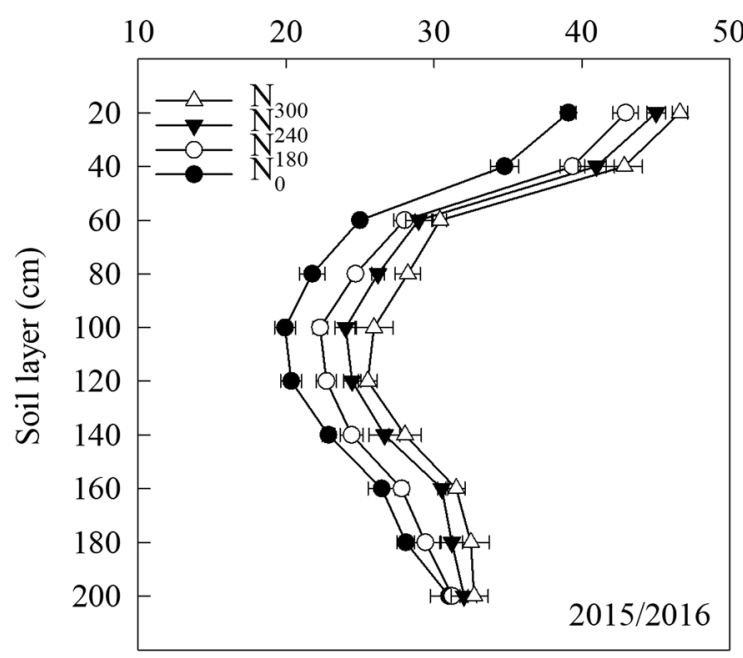

$$
\mathrm{NO}_{3}-\mathrm{N} \text { residue }\left(\mathrm{kg} \mathrm{ha}^{-1}\right)
$$

5010

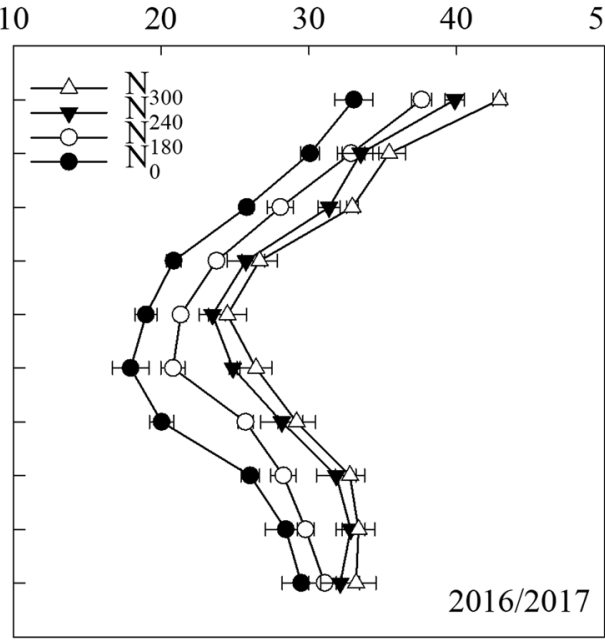

Figure 3. Soil $\mathrm{NO}_{3}-\mathrm{N}$ residue of wheat at maturity under different $\mathrm{N}$ treatments in 2015/2016 and 2016/2017 $\left(\mathrm{kg} \mathrm{ha}^{-1}\right) . \mathrm{N}_{300}, \mathrm{~N}_{240}, \mathrm{~N}_{180}$ and $\mathrm{N}_{0}$ represent $\mathrm{N}$ application rate at $300,240,180$ and $0 \mathrm{~kg} \mathrm{~N}^{-1}$, respectively. Vertical bars represent standard deviation of the means.

the spike number by 4.66 and $13.49 \%$ in $2015 / 2016$ and 2016/2017, respectively, with no obvious differences between $\mathrm{N}_{180}, \mathrm{~N}_{240}$ and $\mathrm{N}_{300}$. No substantial differences were found in grain number per spike among all $\mathrm{N}$ treatments, and the highest 1000-grain weight was observed with $\mathrm{N}_{0}$ in both years. The response of grain yield to the applied $\mathrm{N}$ rate fit a linear-plateau model (Fig. 4), and sharply increased up to $\mathrm{N}_{180}$, by 23.31 and $14.23 \%$ over $\mathrm{N}_{0}$ in $2015 / 2016$ and 2016/2017, respectively. No obvious differences were detected in grain yield among the $\mathrm{N}_{180}, \mathrm{~N}_{240}$, and $\mathrm{N}_{300}$ treatments in either year.

The grain protein concentration and grain protein yield were significantly affected by $\mathrm{N}$ and year (Table 3 ). $\mathrm{N}_{180}$ resulted in a higher grain protein concentration and grain protein yield than $\mathrm{N}_{0}$, and no obvious difference was found between $\mathrm{N}_{240}$ and $\mathrm{N}_{300}$. The highest $\mathrm{PFP}_{\mathrm{N}},{ }^{G} \mathrm{RE}_{\mathrm{N}}$, and $\mathrm{RE}_{\mathrm{N}}$ were obtained with $\mathrm{N}_{180}$. When $\mathrm{N}$ 


\begin{tabular}{|c|c|c|c|c|c|c|c|c|c|c|}
\hline Year & Treatment & $\begin{array}{l}\text { Spike number } \\
\left(\mathbf{m}^{-2}\right)\end{array}$ & $\begin{array}{l}\text { Grain number } \\
\text { per spike }\end{array}$ & $\begin{array}{l}\text { 1000-grain } \\
\text { weight }(\mathrm{g})\end{array}$ & $\begin{array}{l}\text { Grain yield } \\
\left(\mathrm{t} \mathrm{ha^{-1 } )}\right.\end{array}$ & $\begin{array}{l}\text { Grain protein } \\
\text { concentration (\%) }\end{array}$ & $\begin{array}{l}\text { Grain protein } \\
\text { yield }\left(\mathrm{t} \mathrm{ha}^{-1}\right)\end{array}$ & $\begin{array}{l}\mathrm{PFP}_{\mathrm{N}} \\
\left(\mathrm{kg} \mathrm{kg}^{-1}\right)\end{array}$ & $\begin{array}{l}{ }^{{ }^{G}} \mathrm{RE}_{\mathrm{N}} \\
(\%)\end{array}$ & $\begin{array}{l}\mathbf{R E}_{\mathrm{N}} \\
(\%)\end{array}$ \\
\hline \multirow[t]{4}{*}{$2015 / 2016$} & $\mathrm{~N}_{300}$ & $592 a$ & $33.4 \mathrm{a}$ & $42.2 \mathrm{~b}$ & 7.51a & $14.8 \mathrm{ab}$ & $1.11 \mathrm{a}$ & $25.0 \mathrm{c}$ & $15.6 \mathrm{~b}$ & $22.7 \mathrm{~b}$ \\
\hline & $\mathrm{N}_{240}$ & $594 \mathrm{a}$ & $33.4 \mathrm{a}$ & $42.4 \mathrm{~b}$ & $7.73 a$ & $14.9 \mathrm{a}$ & $1.15 \mathrm{a}$ & $32.2 \mathrm{~b}$ & $22.7 \mathrm{a}$ & $32.3 \mathrm{a}$ \\
\hline & $\mathrm{N}_{180}$ & $584 \mathrm{a}$ & $33.1 \mathrm{a}$ & $43.2 \mathrm{ab}$ & $7.67 \mathrm{a}$ & $14.5 \mathrm{~b}$ & $1.11 \mathrm{a}$ & $42.6 \mathrm{a}$ & $26.5 \mathrm{a}$ & $34.6 \mathrm{a}$ \\
\hline & $\mathrm{N}_{0}$ & $558 \mathrm{~b}$ & $32.7 \mathrm{a}$ & $43.7 \mathrm{a}$ & $6.22 \mathrm{~b}$ & $13.5 \mathrm{c}$ & $0.84 \mathrm{~b}$ & - & - & - \\
\hline \multirow[t]{4}{*}{$2016 / 2017$} & $\mathrm{~N}_{300}$ & $616 a$ & $33.4 \mathrm{a}$ & $40.9 \mathrm{~b}$ & $8.65 \mathrm{a}$ & $14.4 \mathrm{a}$ & $1.24 \mathrm{~b}$ & $28.8 \mathrm{c}$ & $18.6 \mathrm{~b}$ & $24.2 \mathrm{~b}$ \\
\hline & $\mathrm{N}_{240}$ & $637 \mathrm{a}$ & $34.0 \mathrm{a}$ & $41.0 \mathrm{~b}$ & $9.25 \mathrm{a}$ & $14.4 \mathrm{a}$ & $1.34 \mathrm{a}$ & $38.5 \mathrm{~b}$ & $29.8 \mathrm{a}$ & $38.0 \mathrm{a}$ \\
\hline & $\mathrm{N}_{180}$ & $614 a$ & $33.7 \mathrm{a}$ & $41.5 \mathrm{~b}$ & $8.83 a$ & $14.7 \mathrm{a}$ & $1.30 \mathrm{ab}$ & $49.1 \mathrm{a}$ & $36.1 \mathrm{a}$ & $43.7 \mathrm{a}$ \\
\hline & $\mathrm{N}_{0}$ & $541 \mathrm{~b}$ & $32.9 \mathrm{a}$ & $44.7 \mathrm{a}$ & $7.73 \mathrm{~b}$ & $12.0 \mathrm{~b}$ & $0.93 \mathrm{c}$ & - & - & - \\
\hline \multicolumn{11}{|l|}{ ANOVA } \\
\hline Nitrogen $(\mathrm{N})$ & & $* * *$ & ns & $* * *$ & $* * *$ & $* * *$ & $* * *$ & $* * *$ & $* * *$ & $* * *$ \\
\hline Year $(\mathrm{Y})$ & & $* *$ & ns & $* *$ & $* * *$ & $* *$ & $* * *$ & $* * *$ & $* *$ & $* *$ \\
\hline $\mathrm{N} \times \mathrm{Y}$ & & *** & ns & $* *$ & ns & $* *$ & ns & ns & ns & ns \\
\hline
\end{tabular}

Table 3. Yield components, yield, grain protein yield and $\mathrm{N}$ utilization of wheat under different $\mathrm{N}$ treatments in 2015/2016 and 2016/2017. $\mathrm{N}_{300}, \mathrm{~N}_{240}, \mathrm{~N}_{180}$ and $\mathrm{N}_{0}$ represent $\mathrm{N}$ application rate at 300, 240, 180 and $0 \mathrm{~kg} \mathrm{~N} \mathrm{ha}^{-1}$, respectively. $\mathrm{PFP}_{\mathrm{N}}, \mathrm{N}$ partial factor productivity, ${ }^{\mathrm{G}} \mathrm{RE}_{\mathrm{N}}$, Grain $\mathrm{N}$ recovery efficiency, $\mathrm{RE}_{\mathrm{N}}, \mathrm{N}$ recovery efficiency. Different letters indicate statistical significance at $\mathrm{P}<0.05$ among treatments. ${ }^{*}$ Significant at $\mathrm{P}<0.05$.

$* *$ Significant at $\mathrm{P}<0.01$. ***Significant at $\mathrm{P}<0.001$. ns, not significant, $\mathrm{P} \geq 0.05$.

\begin{tabular}{|l|l|l|l|l|l|l|l|l|l|}
\hline & STSNT & LNT & STSNE & LNE & GY & GPY & PFP $_{\mathbf{N}}$ & ${ }^{\mathbf{R E}_{\mathbf{N}}}$ & $\mathbf{R E}_{\mathbf{N}}$ \\
\hline STSNT & 1 & & & & & & & & \\
\hline LNT & $0.923^{* *}$ & 1 & & & & & & & \\
\hline STSNE & $0.407^{*}$ & $0.641^{* *}$ & 1 & & & & & & \\
\hline LNE & $0.729^{* *}$ & $0.625^{* *}$ & 0.031 & 1 & & & & & \\
\hline GY & $0.650^{* *}$ & 0.400 & -0.351 & $0.750^{* *}$ & 1 & & & & \\
\hline GPY & $0.871^{* *}$ & $0.676^{* *}$ & -0.019 & $0.775^{* *}$ & $0.915^{* *}$ & 1 & & & \\
\hline PFP $_{\mathrm{N}}$ & 0.334 & -0.278 & -0.068 & $0.775^{* *}$ & 0.432 & 0.453 & 1 & & \\
\hline${ }^{6} \mathrm{RE}_{\mathrm{N}}$ & $0.569^{*}$ & -0.313 & -0.195 & $0.642^{* *}$ & $0.547^{*}$ & $0.580^{*}$ & $0.877^{* *}$ & 1 & \\
\hline $\mathrm{RE}_{\mathrm{N}}$ & $0.582^{*}$ & -0.186 & -0.110 & $0.590^{* *}$ & $0.505^{*}$ & $0.552^{*}$ & $0.885^{* *}$ & $0.951^{* *}$ & 1 \\
\hline
\end{tabular}

Table 4. Correlation analysis of $\mathrm{N}$ translocation, grain yield, grain protein yield, $\mathrm{N}$ partial factor productivity $\left(\mathrm{PFP}_{\mathrm{N}}\right)$, grain $\mathrm{N}$ recovery efficiency $\left({ }^{G} \mathrm{RE}_{\mathrm{N}}\right)$ and $\mathrm{N}$ recovery efficiency $\left(\mathrm{RE}_{\mathrm{N}}\right)$ in $2015 / 2016$ and $2016 / 2017$ $(\mathrm{n}=24)$. STSNT, Stem and sheath N translocation amount; LNT, Leaf N translocation amount; STSNE, Stem and sheath $\mathrm{N}$ translocation efficiency; LNE, Leaf N translocation efficiency; GY, Grain yield; GPY, Grain protein yield. *Correlation is significant at the 0.05 level (2-tailed). **Correlation is significant at the 0.01 level (2-tailed).
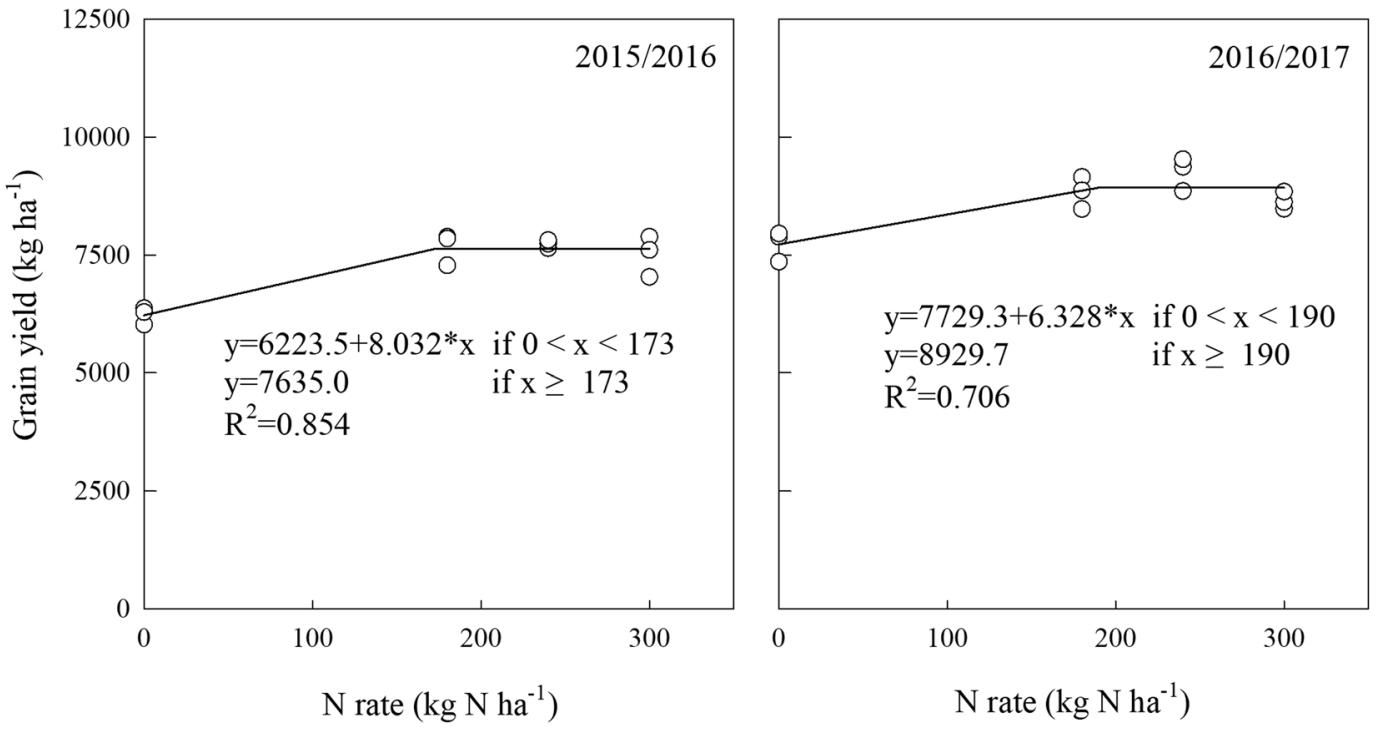

Figure 4. Linear-plateau model fitted for wheat yield as function of $\mathrm{N}$ application rate in 2015/2016 and 2016/2017. 
was increased to $\mathrm{N}_{240}$, the $\mathrm{PFP}_{\mathrm{N}}$ with $\mathrm{N}_{240}$ decreased by 24.41 and $21.59 \%$ compared with $\mathrm{N}_{180}$, respectively, in $2015 / 2016$ and 2016/2017, and there were no significant increases in ${ }^{G} R_{N}$ and $R_{N}$. The lowest $P F P_{N},{ }^{G} R E_{N}$, and $\mathrm{RE}_{\mathrm{N}}$ were found with $\mathrm{N}_{300}$.

Correlation studies. Grain yield was positively correlated with stem and sheath $\mathrm{N}$ translocation amount $(\mathrm{r}=0.650)$ and leaf $\mathrm{N}$ translocation efficiency $(\mathrm{r}=0.750)$ (Table 4). Grain protein yield was positively correlated with stem and sheath $\mathrm{N}$ translocation amount $(\mathrm{r}=0.871)$, leaf $\mathrm{N}$ translocation amount $(\mathrm{r}=0.676)$, and leaf $\mathrm{N}$ translocation efficiency $(r=0.775)$, but not with stem and sheath $\mathrm{N}$ translocation efficiency. ${ }^{\mathrm{G}} \mathrm{RE}_{\mathrm{N}}$ was positively correlated with stem and sheath $\mathrm{N}$ translocation amount $(\mathrm{r}=0.569)$, leaf $\mathrm{N}$ translocation efficiency $(\mathrm{r}=0.642)$, grain yield $(\mathrm{r}=0.547)$, grain protein yield $(\mathrm{r}=0.580)$, and strongly positively correlated with $\operatorname{PFP}_{\mathrm{N}}(\mathrm{r}=0.877)$ and $\mathrm{RE}_{\mathrm{N}}(\mathrm{r}=0.951)$.

\section{Discussion}

$\mathrm{N}$ accumulation and distribution in response to $\mathbf{N}$ application. High levels of $\mathrm{N}$, ranging from 600 to $800 \mathrm{~kg} \mathrm{~N} \mathrm{ha}^{-1}$, have been applied annually for intensive agriculture over several decades in the NCP, along with excessive irrigation (300-400 $\mathrm{mm}$ ) during the wheat growing season in farmers' fields, leading to a rapid decline in the groundwater table and challenges in sustainability ${ }^{24-26}$. Therefore, the optimization of $\mathrm{N}$ supply to wheat requirements should consider moderate irrigation methods on the basis of water-saving in this area. $\mathrm{N}$ accumulation and redistribution are crucial when determining grain quality and yield ${ }^{27,28}$. In leaves, amino acids in proteins are broken down into free amino acids that are stored in leaves and then transported to the grains through the stem, influencing the grain protein content ${ }^{29}$. In this study, treatment with $180 \mathrm{~kg} \mathrm{~N} \mathrm{ha}^{-1}$ maintained a higher level of free amino acid content in the flag leaf and grain after anthesis compared with $0 \mathrm{~kg} \mathrm{~N}^{-1}$ (Fig. 1A,B). This resulted in higher $\mathrm{N}$ being distributed in grain at maturity leading to the increase in grain $\mathrm{N}$ protein concentration, which indicated that $\mathrm{N}$ input accelerated the export of more free amino acids to grains, where it was beneficial for protein synthesis. Approximately $60-95 \%$ of the grain $\mathrm{N}$ at maturity relies on the remobilization of $\mathrm{N}$ stored in the shoots and roots of wheat before anthesis ${ }^{11,30}$, which is influenced by water condition, $\mathrm{N}$ supply, and genotype ${ }^{31,32}$. Following application of $\mathrm{N}$ at $200 \mathrm{~kg} \mathrm{ha}^{-1}$, the vegetative organs of wheat were found to transfer $84.0 \%$ of stored $\mathrm{N}$ to the ears during grain filling, which reduced to $79.0 \%$ at $0 \mathrm{~kg} \mathrm{~N} \mathrm{ha}^{-133}$. $\mathrm{N}$ remobilization in durum wheat plants were increased by $\mathrm{N}$ availability and decreased by water stres $\mathrm{s}^{34}$. When $\mathrm{N}$ was supplied at $240 \mathrm{~kg} \mathrm{~N} \mathrm{ha}^{-1}$, SI based on soil moisture in the $0-40 \mathrm{~cm}$ soil layer improved $\mathrm{N}$ distribution from vegetable organs to grains ${ }^{35}$. In our study, soil water content with $70 \%$ and $65 \%$ of FC at jointing and anthesis were achieved under SI by measuring the moisture in the $0-40 \mathrm{~cm}$ soil layer, $180 \mathrm{~kg} \mathrm{~N} \mathrm{ha}^{-1}$ obtained a higher $\mathrm{N}$ translocation efficiency in the STS and leaf than other $\mathrm{N}$ treatments (Table 2), and did not decrease the $\mathrm{N}$ distributed in the spike stalk and shell and grains at maturity compared with $240 \mathrm{~kg} \mathrm{~N} \mathrm{ha}^{-1}$ and $300 \mathrm{~kg} \mathrm{~N} \mathrm{ha}^{-1}$ (Fig. 2). This suggests that enhancing the translocation efficiency of $\mathrm{N}$ fertilizer at a low level of $\mathrm{N}$ application is a good method to improve the grain $\mathrm{N}$ accumulation of wheat.

Responses of soil NO3-N residue to $\mathrm{N}$ application. High residual $\mathrm{NO}_{3}-\mathrm{N}$ in the $0-200 \mathrm{~cm}$ soil profile in the majority of farmland in China is the result of a long period of heavy $\mathrm{N}$ application ${ }^{36}$. Furthermore, excessive fertilization can contribute to a 6-19\% reduction in apparent $\mathrm{N}$ recovery efficiency, and a $30-93 \%$ increase in soil $\mathrm{NO}_{3}-\mathrm{N}$ residue ${ }^{37}$. Irrigation also affects nitrate leaching ${ }^{38}$, and nitrate leaching into groundwater has been found to account for $29.7-47.9 \%$ of applied $\mathrm{N}$ following irrigation from 104 to $400 \mathrm{~mm}$ and the application of $\mathrm{N}$ fertilization from 104 to $400 \mathrm{~kg} \mathrm{ha}^{-139}$. SI with suitable SRWC in the $0-40 \mathrm{~cm}$ soil layer can reduce $\mathrm{NO}_{3}-\mathrm{N}$ leaching, resulting in a higher output of soil $\mathrm{N}^{35}$. In the present study, the $\mathrm{NO}_{3}-\mathrm{N}$ residue in the $0-180 \mathrm{~cm}$ soil profile increased with increasing $\mathrm{N}$ application in both years (Fig. 3). Application of $180 \mathrm{~kg} \mathrm{~N}^{-1}$ reduced the soil $\mathrm{NO}_{3}-\mathrm{N}$ residue in the $60-180 \mathrm{~cm}$ layer compared with application of 240 and $300 \mathrm{~kg} \mathrm{~N} \mathrm{ha}^{-1}$ under SI in both years (Fig. 3). This indicates that leaching of $\mathrm{NO}_{3}-\mathrm{N}$ at deeper soil depths can be reduced with application of $180 \mathrm{~kg} \mathrm{~N}$ $\mathrm{ha}^{-1}$, which might be due to the lower $\mathrm{N}$ supply as well as the higher $\mathrm{N}$ translocation efficiency in the STS and leaf in winter wheat during the growing stages.

Responses of yield and $\mathbf{N}$ utilization to $\mathbf{N}$ application. Crop yield is strongly influenced by $\mathrm{N}$ fertilizer and varies due to differences in the soil water content ${ }^{40,41}$. N input at $100 \mathrm{~kg} \mathrm{~N}$ ha $^{-1}$ with $120 \mathrm{~mm}$ increased the spike number and 1000-grain weight, leading to a higher grain yield compared with $\mathrm{N}$ input at $200 \mathrm{~kg} \mathrm{~N} \mathrm{ha}^{-1}$ with $180 \mathrm{~mm}^{15}$. At 80 or $70 \%$ full irrigation, a significant increase in yield was recorded up to $80 \mathrm{~kg} \mathrm{~N} \mathrm{ha}^{-1}$, while under water-limiting conditions ( 60 or $50 \%$ full irrigation), a significant increase in yield was only recorded up to $40 \mathrm{~kg} \mathrm{~N} \mathrm{ha}^{-142}$. SI can clearly affect the soil moisture content ${ }^{43}$. In our study, under SI based on RSWC, reducing the $\mathrm{N}$ input to $180 \mathrm{~kg} \mathrm{~N} \mathrm{ha}^{-1}$ maintained the grain yield at a high level for 2 years $\left(7.67 \mathrm{t} \mathrm{ha}^{-1}\right.$ in $2015 / 2016,8.83$ $\mathrm{t} \mathrm{ha}^{-1}$ in 2016/2017) (Table 3). This was mainly attributed to the increase in spike number and the grain number per spike; there was no significant increase in grain yield when $\mathrm{N}$ input increased to 240 and $300 \mathrm{~kg} \mathrm{ha}^{-1}$. Similar 1000 -grain weights were observed with 180 and $0 \mathrm{~kg} \mathrm{~N} \mathrm{ha}^{-1}$ in $2015 / 2016$, but were lower than that of $0 \mathrm{~kg} \mathrm{~N} \mathrm{ha}^{-1}$ in 2016/2017 (Table 3). This may be due to the marked increase in spike number per $\mathrm{m}^{2}$ in $180 \mathrm{~kg} \mathrm{~N} \mathrm{ha}^{-1}$, and monthly precipitation fluctuations (Table 3; Fig. S1). As yield components are usually reported to provide a snapshot of the final yield composition ${ }^{44}$, the number of spikes per $\mathrm{m}^{2}$ is somewhat driven by environmental factors ${ }^{45}$.

Higher grain $\mathrm{N}$ content and lower loss of $\mathrm{N}$ lead to higher $\mathrm{N}$ use efficiency, contributing to a more optimal $\mathrm{N}$ balance ${ }^{3}$. In our study, $180 \mathrm{~kg} \mathrm{~N} \mathrm{ha}^{-1}$ did not significantly decrease the grain yield or grain protein concentration, and there was no decrease in grain protein yield compared with 240 and $300 \mathrm{~kg} \mathrm{~N} \mathrm{ha}^{-1}$. Furthermore, $180 \mathrm{~kg} \mathrm{~N}$ $\mathrm{ha}^{-1}$ significantly increased the $\mathrm{PFP}_{\mathrm{N}}$ compared with 240 and $300 \mathrm{~kg} \mathrm{~N} \mathrm{ha}^{-1}$ and obtained the highest ${ }^{G} \mathrm{RE}_{\mathrm{N}}$ and $\mathrm{RE}_{\mathrm{N}}$. Wheat were able to tolerate $180 \mathrm{~kg} \mathrm{~N} \mathrm{ha}^{-1}$, with no decrease in grain yield or grain protein yield, since 
'non-detrimental' deficiencies can enhance the environmental and economic performance of wheat by increasing $\mathrm{N}$ use efficiency ${ }^{46}$. Additionally, leaf $\mathrm{N}$ translocation efficiency was positively correlated with grain yield, grain protein yield, $\mathrm{PFP}_{\mathrm{N}},{ }^{\mathrm{G}} \mathrm{RE}_{\mathrm{N}}$, and $\mathrm{RE}_{\mathrm{N}}$ (Table 4), indicating that improving $\mathrm{N}$ translocation efficiency in the leaf may be conducive to the increase grain yield, grain protein yield, and $\mathrm{N}$ utilization. Grain yield was positively correlated with $\mathrm{RE}_{\mathrm{N}}$, similar to the results reported by Ye et al. ${ }^{47} . \mathrm{N}$ translocation efficiency in the STS was not closely related to grain yield or grain protein yield (Table 4). This may be because most reserves are stored in the stem and only remobilized with low efficiency, and dry matter of stem requires a minimum protein content to retain the function of material transportation and provide mechanical support ${ }^{14}$. We conclude that under SI, $180 \mathrm{~kg} \mathrm{~N} \mathrm{ha}^{-1}$ is an appropriate $\mathrm{N}$ fertilization rate to maintain high grain yield, grain protein yield and high $\mathrm{N}$ use of winter wheat in the NCP.

\section{Conclusion}

Under SI with 70\% RSWC at jointing and $65 \%$ RSWC at anthesis, $180 \mathrm{~kg} \mathrm{~N}$ ha $^{-1}$ promoted an increase in grain yield, grain protein yield, and $\mathrm{N}$ use in winter wheat by increasing the free amino acid content in the flag leaf and grain after anthesis; the dry matter and plant $\mathrm{N}$ accumulation, and $\mathrm{N}$ translocation in the STS and leaf, which also led to higher $\mathrm{N}$ distribution in grains. $\mathrm{N}$ translocation efficiency in leaf was positively related to grain yield, grain protein yield, $\mathrm{PFP}_{\mathrm{N}},{ }^{G} \mathrm{RE}_{\mathrm{N}}$, and $\mathrm{RE}_{\mathrm{N}}$. Application of $\mathrm{N}$ at $180 \mathrm{~kg} \mathrm{~N} \mathrm{ha}^{-1}$ was optimal for wheat production, and could maintain the grain yield over $7.5 \mathrm{t} \mathrm{ha}^{-1}$ for 2 years. Additional $\mathrm{N}$ input did not further increase the grain yield and grain protein yield, but decreased the $P F P_{N},{ }^{G} E_{N}, R E_{N}$ and increased the soil $N_{3}-N$ residue of the $60-180 \mathrm{~cm}$ soil layer in both seasons, which had potentially unfavorable effects on the environment.

\section{Material and Methods}

Experimental site. Field experiments were carried out between 2015 and 2017 at the experimental farm of Shandong Agricultural University $\left(36^{\circ} 09^{\prime} \mathrm{N}, 117^{\circ} 09^{\prime} \mathrm{E}\right)$, Tai'an, China. This study area has a temperate, semi-humid, and continental monsoon climate, with an annual average temperature of $12.9-13.6^{\circ} \mathrm{C}$ and average annual precipitation of $500-800 \mathrm{~mm}$. Before winter wheat was sown, organic matter, total $\mathrm{N}$, hydrolysable $\mathrm{N}$, available phosphate, and available potassium $(\mathrm{K})$ in the surface soil $(0-20 \mathrm{~cm})$ were $1.50 \%, 0.15 \%, 117.69 \mathrm{mg} \mathrm{kg}^{-1}$, $41.58 \mathrm{mg} \mathrm{kg}^{-1}$, and $133.86 \mathrm{mg} \mathrm{kg}^{-1}$, respectively. The total amounts of precipitation during the wheat growing season in 2015/2016 and 2016/2017 were 184.2 and $180.8 \mathrm{~mm}$, respectively, and monthly total precipitation and mean temperature are shown in Supplementary Fig. S1.

Experimental design. $\mathrm{N}$ was applied at four rates: $300\left(\mathrm{~N}_{300}\right.$, traditional rate of $\mathrm{N}$ applied by farmers $) ; 240$ $\left(\mathrm{N}_{240}, 80 \%\right.$ of the $\mathrm{N}$ application rate $\left.\mathrm{N}_{300}\right) ; 180\left(\mathrm{~N}_{180}, 60 \%\right.$ of the $\mathrm{N}$ application rate $\left.\mathrm{N}_{300}\right)$; and $0\left(\mathrm{~N}_{0}\right) \mathrm{kg} \mathrm{N} \mathrm{ha}^{-1}$. $\mathrm{N}$ fertilizer was applied as urea (46\% $\mathrm{N}$ content) twice: $50 \%$ of $\mathrm{N}$ fertilizer was applied as basic $\mathrm{N}$ fertilizer to the experimental plots before sowing, and the remaining $\mathrm{N}$ was ditched at jointing. The SI for each $\mathrm{N}$ treatment was 70 and $65 \%$ relative soil moisture contents at the jointing and anthesis stages, respectively, in the $0-40 \mathrm{~cm}$ soil layer. The amount of irrigation was calculated using the equation ${ }^{48}: \mathrm{IM}=10 \times \rho \mathrm{b} \times \mathrm{D} \times(\theta \mathrm{i}-\theta \mathrm{j})$, where $\mathrm{IM}(\mathrm{mm})$ is the amount of SI; $\rho \mathrm{b}\left(\mathrm{g} \mathrm{cm}^{-3}\right)$ is the soil bulk density; $\mathrm{D}(\mathrm{cm})$ is the soil profile depth measured for SWC before irrigation $(40 \mathrm{~cm}) ; \theta \mathrm{i}(\%)$ is the target SWC on a weight basis after SI (field capacity $\times$ targeted relative soil water content); and $\theta \mathrm{j}(\%)$ is the SWC on a weight basis before SI. A rotor flowmeter (Huanxiang DN40, China) was used to measure the amount of applied water.

All treatments were applied in triplicate in a randomized design. Each experimental plot was $2 \times 10 \mathrm{~m}$ in size with a $1.0 \mathrm{~m}$ buffer zone between plots to minimize the effects of adjacent plots.

Crop management. Jimai 22, one of the most widely planted wheat cultivars in the NCP, was used in this study. Base fertilizer of $150 \mathrm{~kg} \mathrm{ha}^{-1} \mathrm{P}_{2} \mathrm{O}_{5}$ and $112.5 \mathrm{~kg} \mathrm{ha}^{-1} \mathrm{~K}_{2} \mathrm{O}$ was applied before sowing. Wheat seeds were sown at a density of 225 plants $\mathrm{m}^{-2}$ on 13 October 2015 and 11 October 2016, and were harvested on 10 June 2016 and 9 June 2017.

Sampling and analysis. Plant sampling and analysis. Twenty flag leaves and spikes were sampled $0,7,14$, 21 , and 28 days after anthesis. Fresh samples were immediately frozen in liquid nitrogen and stored at $-40^{\circ} \mathrm{C}$ prior to use in free acetic acid assays. For this, $0.5 \mathrm{~g}$ of fresh samples (flag leaves and grains) was ground with $5 \mathrm{~mL}$ of $10 \%$ acetic acid and then centrifuged at $10,000 \times \mathrm{g}$ and $4{ }^{\circ} \mathrm{C}$ for $10 \mathrm{~min}$. Then, $0.5 \mathrm{~mL}$ of supernatant was made up to a volume of $25 \mathrm{~mL}$ with $\mathrm{pH} 5.4$ acetate buffer to produce the extract, and was then heated in boiling water for $15 \mathrm{~min}$. The free amino acid content was assayed by the ninhydrin method ${ }^{49}$.

Twenty consecutive plants were collected in each plot to estimate dry matter accumulation at pre-winter, revival, jointing, anthesis and maturity of wheat growing stages. At anthesis, the samples were separated into leaves, stems, and glumes, whilst those at maturity were separated into leaves, stems, glumes, and grains. All samples were oven-dried to a constant weight at $80^{\circ} \mathrm{C}$, after heating at $105^{\circ} \mathrm{C}$ for $30 \mathrm{~min}$, and then weighed to determine dry matter.

Next, all samples were milled into powder, which was subsequently used to determine the $\mathrm{N}$ concentration using the Kjeldahl method. The grain protein content was calculated by multiplying the grain $\mathrm{N}$ concentration by the conversion factor, 5.7. The parameters related to $\mathrm{N}$ accumulation and remobilization within the winter wheat were calculated as described by Papakosta and Gagianas ${ }^{31}$ and Wang et al ${ }^{50}$ as follows:

$\mathrm{N}$ accumulation of an organ $\left(\mathrm{kg} \mathrm{ha}^{-1}\right)=\mathrm{N}$ concentration of the organ $\times$ dry weight of the organ;

$\mathrm{N}$ accumulation in a plant $=$ total $\mathrm{N}$ accumulation of all organs at a certain growth stage;

$\mathrm{N}$ translocation amount of an organ $\left(\mathrm{kg} \mathrm{ha}^{-1}\right)=\mathrm{N}$ accumulation of the organ at anthesis $-\mathrm{N}$ accumulation of the organ at maturity; 
Nitrogen translocation efficiency of an organ $(\%)=(\mathrm{N}$ translocation amount of the organ/ $\mathrm{N}$ accumulation of the organ at anthesis) $\times 100$;

Contribution of $\mathrm{N}$ translocation amount from the vegetative organ to the grain $(\%)=(\mathrm{N}$ translocation amount in vegetative organ/grain $\mathrm{N}$ accumulation at maturity) $\times 100$.

Grain yield was determined by all plants harvested in a $2 \mathrm{~m}^{2}$ area of each plot and recorded at a $12.5 \%$ moisture content. All spikes from the sampled area were counted to estimate spike number ha ${ }^{-1}$ for each plot. Twenty stems from each plot were randomly selected to determine the grain number per spike. The 1000-grain weight was determined using grains harvested from each sampled area.

The grain protein yield, $\mathrm{N}$ partial factor productivity $\left(\mathrm{PFP}_{\mathrm{N}}\right)$, grain $\mathrm{N}$ recovery efficiency $\left({ }^{G} \mathrm{RE}_{\mathrm{N}}\right)$, and $\mathrm{N}$ recovery efficiency $\left(\mathrm{RE}_{\mathrm{N}}\right)$ were calculated as follows:

Grain protein yield $\left(\mathrm{t} \mathrm{ha}^{-1}\right)=$ grain protein content $\times$ grain yield;

$\mathrm{PFP}_{\mathrm{N}}\left(\mathrm{kg} \mathrm{kg}^{-1}\right)=$ grain yield in treatments with $\mathrm{N}$ application/amount of applied $\mathrm{N}$;

${ }^{\mathrm{G}} \mathrm{RE}_{\mathrm{N}}(\%)=\left(\right.$ grain $\mathrm{N}$ accumulation in treatments with $\mathrm{N}$ application - grain $\mathrm{N}$ accumulation in $\mathrm{N}_{0}$ )/amount of $\mathrm{N}$ applied $\times 100$;

$\mathrm{RE}_{\mathrm{N}}(\%)=\left(\right.$ total $\mathrm{N}$ accumulation in plant in treatments with $\mathrm{N}$ application - total $\mathrm{N}$ accumulation in plant in $\left.\mathrm{N}_{0}\right) /$ amount of $\mathrm{N}$ applied $\times 100$.

Soil sampling and analysis. Soil samples were collected from each $20 \mathrm{~cm}$ thick soil layer, vertically down to $200 \mathrm{~cm}$ using a soil corer at five points in each plot at maturity. Samples collected from the same soil layer in the same plot were mixed, placed into polyethylene bags, sealed, and then frozen at $-20^{\circ} \mathrm{C}$ before laboratory extraction. Three representative subsamples from each soil layer were extracted using $0.01 \mathrm{~mol} \mathrm{~L}^{-1} \mathrm{CaCl}_{2}$ solu- $^{-}$ tion (NATESC, 2006). $\mathrm{NO}_{3}-\mathrm{N}$ concentration were measured using an ultraviolet spectrophotometer (TU-1901, Presee, China). Soil $\mathrm{NO}_{3}-\mathrm{N}\left(\mathrm{kg} \mathrm{ha}^{-1}\right)$ residue was calculated by the following Equation ${ }^{37}$ :

$$
\mathrm{C}_{\mathrm{NO} 3}=\mathrm{H} \times \rho \mathrm{b} \times \mathrm{c} / 10
$$

where, $\mathrm{C}_{\mathrm{NO} 3}\left(\mathrm{~kg} \mathrm{ha}^{-1}\right)$ is $\mathrm{NO}_{3}-\mathrm{N}$ residue, $\mathrm{H}(\mathrm{cm})$ is soil thickness; $\rho \mathrm{b}\left(\mathrm{g} \mathrm{cm}^{-3}\right)$ is the soil bulk density measured in undisturbed soil samples from each soil layer using $100 \mathrm{~cm}^{3}$ rings; and c $\left(\mathrm{mg} \mathrm{kg}^{-1}\right)$ is the $\mathrm{NO}_{3}-\mathrm{N}_{\text {concentration. }}$.

Statistical analysis. Statistical analyses were performed using standard analysis of variance (ANOVA) in SPSS 22.0. The normality of data and the homogeneity of variances were checked by the Levene and Shapiro-Wilk tests, respectively. An ANOVA was performed to compare the effects of different treatments on the measured variables. To identify significant effects, the means were compared by Duncan's test at $\alpha=0.05$. Two-way ANOVA was performed where $\mathrm{N}$ treatments and year were used as main factors. A linear-plateau model was fitted with SPSS 22.0 to obtain the response of grain yield to $\mathrm{N}$ application rate. Two-tailed Pearson correlation analyses were performed to reveal the relationships among $\mathrm{N}$ translocation, grain yield, grain protein yield, $\mathrm{PFP}_{\mathrm{N}}, \mathrm{RE}_{\mathrm{N}}$ and $\mathrm{RE}_{\mathrm{N}}$ in a combined analysis of data over 2 years.

\section{Data availability}

All data generated or analyzed during this study are included in this published article (and its Supplementary Information files).

Received: 28 November 2019; Accepted: 3 February 2020;

Published online: 24 February 2020

\section{References}

1. Xu, X. X. et al. Improving water use efficiency and grain yield of winter wheat by optimizing irrigations in the North China Plain. Field Crops Res. 221, 219-227 (2018).

2. Cui, Z. L. et al. On-farm evaluation of an in-season nitrogen management strategy based on soil Nmin test. Field Crops Res. 105, 48-55 (2008).

3. Liu, Z. et al. Integrated agronomic practices management improve yield and nitrogen balance in double cropping of winter wheatsummer maize. Field Crops Res. 221, 196-206 (2018).

4. Xiao, G. M. et al. Improving nitrogen and water use efficiency in a wheat-maize rotation system in the North China Plain using optimized farming practices. Agric. Water Manage. 212, 172-180 (2019).

5. Foulkes, M. J. et al. Identifying traits to improve the nitrogen economy of wheat:Recent advances and future prospects. Field Crops Res. 114, 329-342 (2009).

6. Gu, L. M. et al. Lysimeter study of nitrogen losses and nitrogen use efficiency of Northern Chinese wheat. Field Crops Res. 188, 82-95 (2016).

7. Huang, T., Ju, X. T. \& Yang, H. Nitrate leaching in a winter wheat-summer maize rotation on a calcareous soil as affected by nitrogen and straw management. Sci. Rep. 7, 42247 (2017).

8. Wang, H. Y. et al. An optimal regional nitrogen application threshold for wheat in the North China Plain considering yield and environmental effects. Field Crops Res. 207, 52-61 (2017).

9. Bancal, M. O., Roche, R. \& Bancal, P. Late foliar diseases in wheat crops decrease nitrogen yield through N uptake rather than through variations in N remobilization. Ann. Bot. 102, 579-590 (2008).

10. Schierenbeck, M., Fleitas, M. C., Cortese, F., Golik, S. I. \& Simón, M. R. Nitrogen accumulation in grains, remobilization and postanthesis uptake under tan spot and leaf rust infections on wheat. Field Crops Res. 235, $27-37$ (2019).

11. Kong, L. G., Xie, Y., Hu, L., Feng, B. \& Li, S. D. Remobilization of vegetative nitrogen to developing grain in wheat (Triticum aestivum L.). Field Crop. Res. 196, 134-144 (2016).

12. Gaju, O. et al. Identification of traits to improve the nitrogen-use efficiency of wheat genotypes. Field Crops Res. 123, 13-152.

13. Barraclough, P. B. et al. Nitrogen efficiency of wheat: Genotypic and environmental variation and prospects for improvement. Eur. J. Agron. 33, 1-11 (2010). 
14. Pask, A. J. D., Sylvester-Bradley, R., Jamieson, P. D. \& Foulkes, M. J. Quantifying how winter wheat crops accumulate and use nitrogen reserves during growth. Field Crops Res. 126, 104-118 (2012).

15. Zhang, M. M. et al. Yield and water use responses of winter wheat to irrigation and nitrogen application in the North China Plain. J. Integr. Agr. 17, 1194-1206 (2018).

16. Ashraf, U. et al. Maize growth, yield formation and water-nitrogen usage in response to varied irrigation and nitrogen supply under semi-arid climate. Turk. J. Field Crops. 21, 88-96 (2016).

17. Paolo, E. D. \& Rinaldi, M. Yield response of corn to irrigation and nitrogen fertilization in a Mediterranean environment. Field Crops Res. 105, 202-210 (2008).

18. Adrienn, V. S., Attila, M. \& Nagy, J. Irrigation and nitrogen effects on the leaf chlorophyll content and grain yield of maize in different crop years. Agric. Water Manage. 107, 133-144 (2012).

19. Bandyopadhyay, K. K. et al. Effect of irrigation and nitrogen application methods on input use efficiency of wheat under limited water supply in Vertisol of Central India. Irrig. Sci. 28, 285-299 (2010).

20. Rossella, A., Mladen, T., Tatjana, M. \& Anna, M. S. Comparing the interactive effects of water and nitrogen on durum wheat and barley grown in a Mediterranean environment. Field Crops Res. 115, 179-190 (2010).

21. Gholamhoseini, M., AghaAlikhani, M., Modarres Sanavy, S. A. M. \& Mirlatifi, S. M. Interactions of irrigation, weed and nitrogen on corn yield, nitrogen use efficiency and nitrate leaching. Agric. Water Manage. 126, 9-18 (2013).

22. Man, J. G., Yu, Z. W. \& Shi, Y. Radiation interception, chlorophyll fluorescence and senescence of flag leaves in winter wheat under supplemental irrigation. Sci. Rep. 7, 7767 (2017).

23. Wang, D. Water use efficiency and optimal supplemental irrigation in a high yield wheat field. Field Crops Res. 213, 213-220 (2017).

24. Zhang, H. L. et al. Challenges and adaptations of farming to climate change in the North China Plain. Clim. Change. 129, 213-224 (2015).

25. Huang, P. et al. Nitrate accumulation and leaching potential reduced by coupled water and nitrogen management in the HuangHuai-Hai Plain. Sci. Total Environ. 610-611, 1020-1028 (2018).

26. Guo, Y. Q., Zhang, X. N., Yu, X. H. \& Zou, Z. D. The increasing effects in energy and GHG emission caused by groundwater level declines in North China's main food production plain. Agric. Water Managet. 203, 138-150 (2018).

27. Hirel, B., Gouis, J. L., Ney, B. \& Gallais, A. The challenge of improving nitrogen use efficiency in crop plants: towards a more central role for genetic variability and quantitative genetics within integrated approaches. J. Exp. Bot. 58, 2369-2387 (2007).

28. Gaju, O. et al. Nitrogen partitioning and remobilization in relation to leaf senescence, grain yield and grain nitrogen concentration in wheat cultivars. Field Crops Res. 155, 213-223 (2014).

29. Zhao, Y. L. et al. Nitrogen effect on amino acid composition in leaf and grain of japonica rice during grain filling stage. J. Cereal Sci. 64, 29-33 (2015).

30. Kichey, T., Hirel, B., Heumez, E., Dubois, F. \& Gouis, J. L. In winter wheat (Triticum aestivum L.), post-anthesis nitrogen uptake and remobilisation to the grain correlate with agronomic traits and nitrogen physiological markers. Field Crop. Res. 102, 22-32 (2007).

31. Papakosta, D. K. \& Gagianas, A. A. Nitrogen and dry matter accumulation remobilization, and losses for Mediterranean wheat during grain filling. Agron. J. 83, 864-870 (1991)

32. Barbottin, A., Lecompte, C., Bouchard, C. \& Jeuffroy, M. H. Nitrogen remobilization during grain filling in wheat: genotypic and environmental effects. Crop Sci. 45, 1141-1150 (2005).

33. Barraclough, P. B., Lopez-Bellido, R. \& Hawkesford, M. J. Genotypic variation in the uptake, partitioning and remobilisation of nitrogen during grain-filling in wheat. Field Crops Res. 156, 242-248 (2014).

34. Ercoli, L., Lulli, L., Mariotti, M., Masoni, A. \& Arduini, I. Post-anthesis dry matter and nitrogen dynamics in durum wheat as affected by nitrogen supply and soil water availability. Eur. J. Agron. 28, 138-147 (2008).

35. Guo, Z. J., Zhang, Y. L., Zhao, J. Y., Shi, Y. \& Yu, Z. W. Nitrogen use by winter wheat and changes in soil nitrate nitrogen levels with supplemental irrigation based on measurement of moisture content in various soil layers. Field Crops Res. 164, 117-125 (2014),

36. Zhu, Z. L. \& Chen, D. L. Nitrogen fertilizer use in China-Contribution to food production, impacts on the environment and best management strategies. Nutr. Cycl. Agroecosyst. 63, 117-127 (2002).

37. Lu, J. et al. Accumulation and leaching of nitrate in soils in wheat-maize production in China. Agric. Water Manage. 212, 407-415 (2019).

38. Tarkalson, D. D., Payero, J. O., Ensley, S. M. \& Shapiro, C. A. Nitrate accumulation and movement under deficit irrigation in soil receiving cattle manure and commercial fertilizer. Agric. Water Manage 85, 201-210 (2006).

39. Sun, M. et al. Quantifying long-term responses of crop yield and nitrate leaching in an intensive farmland using agro-ecoenvironmental model. Sci. Total Environ 613-614, 1003-1012 (2018).

40. Spiertz, J. H. J. Nitrogen, sustainable agriculture and food security: a review. Agron. Sustain. Dev. 30, 43-55 (2010).

41. Rao, S. S., Regar, P. L., Tanwar, S. P. S. \& Singh, Y. V. Wheat yield response to line source sprinkler irrigation and soil management practices on medium-textured shallow soils of arid environment. Irrig. Sci. 31, 1-13 (2013).

42. Rathore, V. S. et al. Yield, water and nitrogen use efficiencies of sprinkler irrigated wheat grown under different irrigation and nitrogen levels in an arid region. Agric. Water Manage. 187, 232-245 (2017).

43. Mouna, F., Giovanni, R., Alessandro, C. \& Marco, M. Influence of soil hydraulic variability on soil moisture simulations and irrigation scheduling in a maize field. Agric. Water Manage. 202, 183-194 (2018).

44. Gambín, B. L. \& Borrás, L. Resource distribution and the trade-off between seed number and seed weight: a comparison across crop species. Ann. Appl. Biol. 156, 91-102 (2010).

45. Slafer, G. A., Savin, R. \& Sadras, V. O. Coarse and fine regulation of wheat yield components in response to genotype and environment. Field Crops Res. 157, 71-83 (2014)

46. Ravier, C., Meynard, J. M., Cohan, J. P., Gate, P. \& Jeuffroy, M. H. Early nitrogen deficiencies favor high yield, grain protein content and $\mathrm{N}$ use efficiency in wheat. Eur. J. Agron. 89, 16-24 (2017).

47. Ye, Y. S. et al. Alternate wetting and drying irrigation and controlled-release nitrogen fertilizer in late-season rice. Effects on dry matter accumulation, yield, water and nitrogen use. Field Crops Res. 144, 212-224 (2013).

48. Ekren, S. et al. The effect of different irrigation water levels on yield and quality characteristics of purple basil (Ocimum basilicum L.). Agric Water Manage. 109, 155-161 (2012).

49. Chen, Y. Y. et al. Proteolysis of chloroplast proteins is responsible for accumulation of free amino acids in dark-treated tea (Camellia sinensis) leaves. J. Proteomics. 157, 10-17 (2017).

50. Wang, H. G., Guo, Z. J., Shi, Y., Zhang, Y. L. \& Yu, Z. W. Impact of tillage practices on nitrogen accumulation and translocation in wheat and soil nitrate-nitrogen leaching in drylands. Soil Tillage Res. 153, 20-27 (2015).

\section{Acknowledgements}

This work was supported by the National Natural Science Foundation of China (31771717), the Natural Science Foundation of Shandong Province (ZR2016CM34), and the Technology System in Modern Wheat Industry, Ministry of Agriculture, China (CARS-3-1-19).

\section{Author contributions}

Initiated and designed the experiments: X.Z., Z.Y., Y.Z. and Y.S. Performed the experiments: X.Z., Z.Y., Y.Z. and Y.S. Analyzed the data and wrote the manuscript: X.Z. and Z.Y. All authors have reviewed the manuscrip. 


\section{Competing interests}

The authors declare no competing interests.

\section{Additional information}

Supplementary information is available for this paper at https://doi.org/10.1038/s41598-020-59877-5.

Correspondence and requests for materials should be addressed to Y.Z.

Reprints and permissions information is available at www.nature.com/reprints.

Publisher's note Springer Nature remains neutral with regard to jurisdictional claims in published maps and institutional affiliations.

(c) (i) Open Access This article is licensed under a Creative Commons Attribution 4.0 International

License, which permits use, sharing, adaptation, distribution and reproduction in any medium or format, as long as you give appropriate credit to the original author(s) and the source, provide a link to the Creative Commons license, and indicate if changes were made. The images or other third party material in this article are included in the article's Creative Commons license, unless indicated otherwise in a credit line to the material. If material is not included in the article's Creative Commons license and your intended use is not permitted by statutory regulation or exceeds the permitted use, you will need to obtain permission directly from the copyright holder. To view a copy of this license, visit http://creativecommons.org/licenses/by/4.0/.

(c) The Author(s) 2020 